\title{
TECHNICAL EFFICIENCY OF SHALLOTS FARMING ON UPSUS PROGRAM USING STOCHASTIC FRONTIER ANALYSIS (CASE STUDY IN GONDANG SUB-DISTRICT, NGANJUK REGENCY, EAST JAVA, INDONESIA)
}

\author{
Anugrah Rizki Pratama ${ }^{1, *}$, Syafrial $^{2}$, Kliwon Hidayat ${ }^{2}$ \\ '(Master's Degree, Agricultural Economics, University of Brawijaya, Indonesia) \\ ${ }^{2}$ (Lecturer, Agricultural Economics, University of Brawijaya, Indonesia) \\ *Corresponding author: anugrahrizkipratama@gmail.com
}

\begin{abstract}
These study aims to analyze the level of technical efficiency of shallots farming, and to analyze the factors that affect the inefficiency shallots farming in UPSUS APBN-P 2017 Program. This research uses Stochastic Frontier production function analysis method which aims to analyze the level of technical efficiency of shallots farmers in Gondang sub-district. The second analytical method is Tobit regression that aims to determine what factors affect the technical inefficiency in shallots farming in Gondang Sub-district. The result of this research is known that the average value of efficiency achieved is equal to 0.71 . The total of 52 farmers are technically efficient and as many as 38 farmers are technically inefficient. In the result of Tobit regression analysis, it is known that the factors that significantly influence the technical inefficiency of shallots farming in Gondang sub-district are age, farming experience, training participation, and program officer control.
\end{abstract}

Keywords: Frontier production function, shallots farming, technical efficiency, UPSUS Program

\section{INTRODUCTION}

Horticulture subsector is one of the most important parts of economic growth and development in Indonesia, horticulture commodities not only meet national needs but also can meet the needs in international markets which are able to generate foreign exchange and give effect to the improvement of the country's economy. In the last few years, export volume growth from the horizontal sub-sector continued to increase up to $2.69 \%$ per year to the volume of national exports, where vegetable crops contributed $7.39 \%$ per year, $1.74 \%$ fruits per year, $74.73 \%$ per year, and ornamental plants of $25.96 \%$ per year. While the export volume from the horticulture subsector in Indonesia can reach average of $6.33 \%$ per year (Pusdatin Pertanian, 2016).

Shallots is one of the strategic superior commodities in Indonesia. The level of shallots consumption in household needs from year to year also increased by $8.30 \% \mathrm{~kg} /$ capita / year or about $1.65 \mathrm{~kg} / \mathrm{capita} /$ year. Increase in shallots consumption in Indonesia is accompanied by an increase in shallots production which from year to year tends to fluctuate both in terms of productivity and the area of harvested area in Indonesia. The largest production of shallots in Indonesia comes from four provinces of shallots centers namely Central Java, East Java, West Java and West Nusa Tenggara with $85.30 \%$ contribution to total national production (Pusdatin Pertanian, 2016).

Nganjuk Regency is the largest shallots production center in East Java with the contribution of total shallots production in East Java reaches $51.54 \%$ (Ministry of Agriculture, 2016). Red shallots production in Nganjuk regency from year to year tends to fluctuate both from harvested area and production quantity that directly impact on fluctuation of shallots productivity in Nganjuk regency.

Gondang sub-district is one of the central areas of shallots. The sub-district has the largest contribution to the total production of shallots in Nganjuk regency. In 2016, Gondang sub-district produces 288,545 quintals of shallot, while in 2016 Gondang Sub-district can produce 292,504 quintals shallots (BPP of Gondang Sub-district, 2017). 
The decrease in shallots productivity is thought to result from the use of input that has not been optimal. According to Farrel (1957) productivity is closely related to the level of technical efficiency, where technical efficiency is a description of farming ability to produce maximum output with the use of certain input proportions.

In 2017 the government implements a policy to increase self-sufficiency of staple food commodities and horticulture through UPSUS Program. Especially in Nganjuk district this program aims to increase the production of shallotss. The specific problem of shallots farming in Gondang sub-district is low shallots productivity with an average of 10 tons/ha, whereas according to Balitbang Pertanian (2015) with land condition in East Java and using superior varieties of shallots able to produce productivity maximum of about 15 20 tons in one hectare. This is allegedly caused by the use of production factors (land area, seeds, fertilizers, pesticides, and labor) that are not in accordance with the recommended by the PPL and the Agriculture Agency through SOP (Standard Operational Procedural) so that the difference productivity of shallots (Gap) between shallots in UPSUS farmers.

The price of shallots tends to be very fluctuate, based on data from the Office of Agriculture Nganjuk Regency as of October 2017 the price of shallots reaches IDR $11.000 / \mathrm{Kg}$ at the farm level, and according to the latest data as of January 2018 the price of shallots tends to fall to reach IDR $7,000 / \mathrm{Kg}$ at the farm level. The last problem is that the profitability of low shallots farmers is due to the average productivity produced and the low shallots sale price.

According to Khumbakar (2002) the use of technical efficiency is aimed at maximizing the production of goods through the use and combination of certain inputs, so it can be said technically efficient if the farmer is no longer able to produce more production without reducing or adding input. Based on Waryanto (2015) and Purmayanti (2002), examining the technical efficiency of shallots in Brebes Regency, showed that the farming system has been technically efficient. The use of input is optimal. However, a farm that has been categorized technically efficient not be a guarantee that the farm can also be categorized efisiesn allocatively.
Efficiency achieved in the farming becomes a major part to determine the increase of farm productivity, where there are always limitations and constraints on input production (Bifarin, 2010). Basically productivity is very influential on the level of farming efficiency, especially farmer technical efficiency that can be measured from the maximum output that can be obtained from the use of available inputs (Roger, 1998)

Base on the problems, this study aimed: (1) to analyze the level of technical efficiency of shallots farming, and (2) to analyze the factors that affect the inefficiency shallots farming in UPSUS APBN-P 2017 Program.

\section{RESEARCH METHODS}

This study was conducted in Gondang Sub-district, Nganjuk Regency as on of shallots's production center in East Java and has been implemented the UPSUS APBN-P 2017. This research was conducted during February-Mach 2018. Sampling techniques used simple random sampling. The number of samples taken using slovin formula. The calculation of slovin was obtained by the sample of UPSUS shallots's farmer as many 90 people.

The method used in the research is the Stochastic Frontier Production Function that allegedly using Maximum Likelihood Estimation (MLE) with frontier 4.1 software version. The factors that affect of shallots production are the amount of seed, the amount of Urea, $\mathrm{KCl}$, NPK, and ZA fertilizer, the amount of pesticide, and the amount of labour. From the variables of the model estimation equation of frontier production function of the UPSUS shallots farmer in Gondang Subdistrict can be written as follows:

$\mathrm{LnY}_{\mathrm{i}}=\beta_{0}+\beta_{1} \ln \mathrm{BB}+\beta_{2} \ln \mathrm{UR}+\beta_{3} \ln \mathrm{NPK}+$ $\beta_{4} \ln \mathrm{KCl}+\beta_{5} \ln \mathrm{ZA}+\beta_{6} \ln \mathrm{PS}+\beta_{7} \ln \mathrm{TK}$ $+\left(\mathrm{V}_{\mathrm{i}}+\mathrm{U}_{\mathrm{i}}\right)$

Where:

: Production of shallots per hactare (Kg/Ha)

BB : amount of seed $(\mathrm{Kg} / \mathrm{Ha})$

UR : amount of Urea $(\mathrm{Kg})$

NPK : amount of NPK $(\mathrm{Kg})$

$\mathrm{KCl}$ : amount of $\mathrm{KCl}(\mathrm{Kg})$

ZA : amount of ZA $(\mathrm{Kg})$

PS : amount of pesticide (Liter)

TK : amount of labour (labor days=HOK) 

$\beta 0 \quad$ : Intersep
$\mathrm{Vi}+\mathrm{Ui}$ : (Vi) error, $\left(\mathrm{U}_{\mathrm{i}}\right)$ technical inefficiency effect

The technical efficiency of shallots farming is using the formula as follows:

$$
T E=\frac{Y}{Y^{\prime}}=\exp \left(-u_{i}\right)
$$

Where

TE : Technical Efficiency

Y : Actual Production

Y' : Potential Production

Exp (-ui) : Technical Inefficiency Model

To find out the factors that affect the level of technical inefficiency of shallots farming on UPSUS farming in Gondang Sub-district is using tobit regression analysis, Wassie (2012); Geta $e t$ all, (2013) said tobit regression is an analytical tool used for the model developed by Tobin (1958), if the variable does not have limits to be calculated. The aquation as follows:

$$
\begin{aligned}
\mathrm{U}_{\mathrm{i}}= & \delta_{\mathrm{o}}+\delta_{1} \mathrm{US}_{, \mathrm{i}}+\delta_{2} \mathrm{JK}_{, \mathrm{i}}+\delta_{3} \mathrm{TP}_{, \mathrm{i}}+\delta_{4} \mathrm{PU}_{, \mathrm{i}}+ \\
& \delta_{5} \mathrm{TI}_{, \mathrm{i}}+\delta_{6} \mathrm{DT}_{, \mathrm{i}}+\delta_{7} \mathrm{KP}_{, \mathrm{i}}
\end{aligned}
$$

Where:

$$
\begin{array}{ll}
\text { Ui } & : \text { Technical inefficiency } \\
\text { US } & : \text { age (year) } \\
\text { JK } & \text { : Number of family member (person) } \\
\text { TP } & : \text { Education (year) } \\
\text { PU } & : \text { Farming Experience (year) } \\
\text { TI } & : \text { Information and Technology Access } \\
& \text { (dummy) } \\
\text { DI } & : \text { Training Participation (frequency) } \\
\text { KP } & : \text { Program Officer Control (frequency) } \\
\delta_{\mathrm{o}} & : \text { Intercept }
\end{array}
$$

\section{RESULTS AND DISCUSSION}

1. Responden Characteristics

a. Farmers age

Average age of farmers participating in UPSUS shallots is 43 years. The youngest age of farmers participating in UPSUS shallots is 25 years old and farmers participating in UPSUS shallots are the oldest aged 65 years. This means that at a productive age a person is able to be more daring in taking risks in a decision, and more careful in making judgments, at the age of a younger farmer it will be easier to accept a new innovation in farming, but at an older age farmers have had a lot of experience so they can think more rationally.

b. Education

The level of education most often taken by farmers of shallots in Gondang sub-district is the level of elementary school education. In shallots farmers participating in Gondang District, the majority were elementary school graduates with a total of 45 people $(50 \%)$, while the least were 2 college graduates $(2.22 \%)$.

c. Farming experience

Shallots farmers in Gondang Sub-district have an average of 18 years of farming experience where most of the shallots farmers in Gondang Subdistrict have been conducting farming activities since completing formal education. this means that the length of farming experience owned by farmers shows that farmers are skilled and experienced in cultivatingshallotsin Gondang sub-district so that farmers are able to manage their farming properly. The farming experience also affects the managerial decisions of farmers, namely in the use of production factors and cultivation systems that are applied in farming.

\section{Average Input use of farmers}

Table 1. Average farmer's land area

\begin{tabular}{lccc}
\hline \multirow{2}{*}{ No } & $\begin{array}{c}\text { Land area } \\
(\mathrm{Ha})\end{array}$ & $\begin{array}{c}\text { Number of } \\
\text { Responden }\end{array}$ & $\begin{array}{c}\text { Persentage } \\
(\%)\end{array}$ \\
\cline { 3 - 4 } 1 & $0-0.25$ & 51 & 56.66 \\
\hline 2. & $0.26-0.50$ & 23 & 25.56 \\
\hline 3. & $0.51-0.75$ & 11 & 12.22 \\
\hline 4. & $0.76-1.00$ & 4 & 4.44 \\
\hline 5. & $>1.00$ & 1 & 1.11 \\
\hline & Total & 90 & 100 \\
\hline
\end{tabular}

Source: Primary Data 2018 (Remake)

Shallots farmers in Gondang District have a land area that includes in the category of $0-0.25$ hectares with a percentage of more than $55 \%$. On farmer UPSUS shallots farmers number of farmers who have land with an area of $0-0.25$ hectares is as many as 51 people $(56.66 \%)$. In the category of land area $0.26-0.75$ Hectares are as many as 11 people $(12.22 \%)$. As for the land area of more than 1 hectare is only owned by 1 person from farmers participating in shallots UPSUS shallots Gondang sub-district. 
Table 2. average seed use of farmers

\begin{tabular}{lcrr}
\hline No & $\begin{array}{c}\text { Number } \\
\text { of seed } \\
\end{array}$ & $(\mathrm{Kg} / \mathrm{Ha})$ & \multicolumn{2}{c}{$\begin{array}{l}\text { Number } \\
\text { Responden }\end{array}$} & \multicolumn{2}{c}{$\begin{array}{c}\text { of } \\
(\%)\end{array}$} \\
\hline 1. & $100-1000$ & 7 & 7.78 \\
\hline 2. & $1001-2000$ & 68 & 75.56 \\
\hline 3. & $2001-3000$ & 13 & 14.44 \\
\hline 4. & $>3000$ & 2 & 2.22 \\
\hline & Total & 90 & 100 \\
\hline
\end{tabular}

Source : Primary Data 2018 (Remake)

Seeds of shallots used by farmers of UPSUS shallots participants are superior seeds with Bauji varieties, the reason for the use of this variety is due to the matching of seeds with agricultural land in Gondang District. Participants of UPSUS shallots farmers get superior seeds from government assistance when UPSUS APBN-P 2017 Program is implemented. The number of seeds received by each participant of UPSUS shallots farmers amounts to $300 \mathrm{~kg}$ for each farmer listed as beneficiary, and some of the farmers also produce their own seeds as additional seeds to be planted. The other farmers also obtained shallots seeds by buying seeds from breeders at a price of IDR 25.000, - to IDR 30.000, - per kilogram. Average quantity of use of shallots seeds in District Gondang of 1.6 tons /ha.

The quantity of use of shallots seeds is in the range of 1001 - $2000 \mathrm{~kg} / \mathrm{ha}$ for 68 people or $75.56 \%$ of the responden. While the quantity of seedlings use is $>3000 \mathrm{~kg} / \mathrm{ha}$. Moreover, about 2 percent of farmers of UPSUS shallots participants use seeds with an average amount of 1.6 tons / ha.

Table 3. Average fertilizer use of farmers

\begin{tabular}{llc}
\hline No. & \multicolumn{1}{c}{$\begin{array}{c}\text { Number of fertilizer } \\
(\mathrm{Kg} / \mathrm{Ha})\end{array}$} & \begin{tabular}{c} 
UPSUS Farmers \\
\cline { 3 - 3 }
\end{tabular} \\
\hline 1. & Urea & 295.98 \\
\hline 2. & $\mathrm{KCl}$ & 297.96 \\
\hline 3. & NPK & 323.37 \\
\hline 4. & ZA & 471.97 \\
\hline
\end{tabular}

Source : Primary Data 2018 (Remake)

Chemical fertilizers used by the farmers are urea, $\mathrm{KCl}, \mathrm{NPK}$, and ZA. Farmers of shallots respondents obtain fertilizer from shops and farm kiosks in the District Gondang.Farmers of UPSUS shallots participants use a proportion of fertilizer with a large proportion and not balanced. This is because farmers assume that by applying more fertilizer it can increase the production of shallots significantly and the amount of fertilizer use caused by the influence of the land during the rainy season because the fertilizer that has been applied to the crop is very quickly washed and tebawa by rain water so the need fertilizer on the plant should be added.

Based on research from Mutiarasari (2017) the average use of chemical fertilizers for shallots commodities is for urea fertilizer on average need $138 \mathrm{~kg} / \mathrm{ha}, \mathrm{KCl}$ fertilizer requires $177 \mathrm{~kg} / \mathrm{ha}$, NPK fertilizer requires $187 \mathrm{~kg} / \mathrm{ha}$, and fertilizer ZA 228 $\mathrm{kg} / \mathrm{ha}$. So this can affect the efficiency level of shallots farming system. While the recommendation from Vegetable Crops Research Institute for the use of chemical fertilizers for urea is as much as $179 \mathrm{~kg} / \mathrm{ha}, \mathrm{KCl}$ fertilizer as much as $200 \mathrm{~kg} / \mathrm{ha}$, NPK as much as $200 \mathrm{~kg} / \mathrm{ha}$, and ZA as much as $300 \mathrm{~kg} / \mathrm{ha}$.

Table 4. Average labor use of farmers

\begin{tabular}{|c|c|c|c|}
\hline \multirow[b]{2}{*}{ No. } & \multirow[b]{2}{*}{$\begin{array}{c}\text { Number of } \\
\text { labor }\end{array}$} & \multicolumn{2}{|c|}{ UPSUS Farmers } \\
\hline & & $\begin{array}{l}\text { Number of } \\
\text { Responden }\end{array}$ & $\begin{array}{c}\text { Persentage } \\
(\%)\end{array}$ \\
\hline 1. & $150-350$ & 34 & 37.78 \\
\hline 2. & $350-500$ & 47 & 52.22 \\
\hline 3. & $>500$ & 9 & 10.00 \\
\hline & Total & 90 & 100 \\
\hline
\end{tabular}

Source: Primary Data 2018 (Remake)

The use of labor in shallots farming activities in Kecamatan Gondang includes preparatory activities and land preparation, shallots seed planting, fertilizing, irrigation, pesticide spraying, weeding, harvesting and post harvesting activities. Workers in shallots farming is divided into two namely male labor and female labor. Male labor usually performs activities such as cultivation of land, fertilization, irrigation, and spraying of pesticides. While women workforce do planting activities of seed and harvest. For wages received by male laborers in a day is IDR 65,000 up to IDR 70,000 with a working time of 8 hours. Moreover, for the female worker earns a wage of IDR 55,000 up to IDR 60,000 with a long working time of 6 hours.

Based on the explanation in table 14 the number of labor usage by farmers of UPSUS shallots participant in Gondang Sub-district is highest in the range $350-500 \mathrm{HOK}$, with farmers of UPSUS shallots participants as much as 47 people or with percentage of $52.22 \%$ while the smallest which is in the range> $500 \mathrm{HOK}$ is as much as 9 people or with a percentage of $10 \%$. The 
average use of labor for shallots farming in Kecamatan Gondang is 388 HOK per Hectare. The use of this workforce is low compared to Apriani (2011) where for one hectare of shallots land requires an average workforce of 490 people. This is caused by the lack of availability of agricultural labor in Nganjuk regency, especially in Gondang sub-district so that the use of labor is not maximal and the shallots farmers must bring in the labor of agricultural laborers from outside the region.

3. Technical Efficiency Analysis of Shallots Farming on UPSUS APBN-P 2017 Program in Gondang Sub-district.

Analysis of technical efficiency level on shallots farming aims to know the highest level of efficiency and the lowest efficiency and average efficiency achieved by farmers in the shallots farm in Gondang Subdistrict. The level of efficiency achieved by the respondents in the study area can be seen in Table 5 .

Table 5. The Result of Technical Efficiency of Shallots Farming in Gondang Sub-district

\begin{tabular}{lcc}
\hline \multirow{2}{*}{$\begin{array}{c}\text { Technical } \\
\text { Efficiency } \\
\text { Value }\end{array}$} & \multicolumn{2}{c}{ UPSUS Farmer } \\
\cline { 2 - 3 }$\leq 0.699$ & $\begin{array}{c}\text { Number } \\
\text { of Farmer }\end{array}$ & $\begin{array}{c}\text { Percentage } \\
(\%)\end{array}$ \\
\hline $0.700-0.900$ & 38 & 42.22 \\
\hline$>0.900$ & 11 & 45.56 \\
\hline Total & 90 & 12.22 \\
\hline Minimum 0.36 & & 100.00 \\
\hline Maximum 0.95 & \\
\hline Average 0.71 & \\
\hline Source : Primary Data 2018 (Remake)
\end{tabular}

The level of technical efficiency achieved by UPSUS shallots farmers are from 0.36 to 0.95 . The proportion of the highest level of efficiency is spread on categories $(0.700-0.900)$ as many as 41 farmers of UPSUS shallots participants with a percentage of $45.56 \%$. While for the level of technical efficiency in the highest category (> 0.900 ) that is 11 farmers with percentage of $12.22 \%$ and technical efficiency value below average is $\leq 0.699$ as many as 38 people or with a percentage of $42.22 \%$.

The average efficiency of shallots farming on the farmers of UPSUS shallots participants in Gondang Sub-district is 0.71 which means that the level of technical efficiency achieved is good. The highest level of efficiency achieved by shallots farmers of UPSUS participant in Gondang Subistrict is 0.95 , which means that farmers have been able to achieve a $95 \%$ technical efficiency level of shallots production potential by combining input production use. While the lowest level of technical efficiency achieved by shallots farmers UPSUS participant is 0.36 which means Technical efficiency level achieved only by $36 \%$ of the potential of shallots production by combining input production.

As many as 52 farmers or $57.78 \%$ of the total number of shallots farmer of UPSUS participant in Gondang Sub-district have been technically efficient. While as many as 38 shallots farmer of UPSUS participant in Gondang Sub-district or $42.22 \%$ of the total number of shallots farmers of UPSUS participant Gondang Sub-district has not reached the level of technical efficiency because the technical efficiency level is still less than 0,70 . This lower level of technical efficiency shows the ability of shallots farmer of UPSUS participant and the other factors can be climate and weather and othe uncontrollable factors.

4. Factors Affecting the Technical Inefficiency of Shallots Farming in Gondang Sub-district.

In this study, factors included in the model are farmer age, experience of farming, education level, number of family members, access to technology and information, participation of thematic UPSUS training, and control of UPSUS Program Officers. The results of inefficiency effect analysis can be seen in Table 6.

The value of log likelihood ratio of 51.44 which means the value is greater than the significant level of $0.05\left(X^{2}>\right.$ Chi Square table value) where can be obtained the hypothesis that reject $\mathrm{H}_{0}$ and receive $\mathrm{H}_{1}$. Then it can be concluded that simultaneously the age factor of farmers, the number of family members, the level of education, farming experience, access to information and technology, the participation of the Training Program UPSUS APBN-P 2017, and control officers UPSUS Program APBN-P 2017 have simultaneous influence on inefficiency technical shallots farming of UPSUS participant in Gondang Sub-district. 

Table 6. Tobit Regression Analysis Results of Factors Affecting Technical Inefficiency of Shallots Farming in Gondang Sub-district

\begin{tabular}{lcccc}
\hline \multirow{2}{*}{ Variable } & \multicolumn{3}{c}{ Tobit Regression Analysis } \\
\cline { 2 - 4 } & Coefficient & S.E & Z-Stat & Prob \\
\hline C & 0.412 & 0.124 & 3.302 & 0.0010 \\
Age & 0.005 & 0.002 & 2.173 & $0.0297 * *$ \\
Number of Family Member & 0.017 & 0.016 & 1.101 & 0.2708 \\
Education Level & -0.001 & 0.005 & -0.269 & 0.7877 \\
Farming Experience & -0.012 & 0.003 & -3.665 & $0.0002^{* * *}$ \\
Information Access & -0.016 & 0.039 & 0.431 & 0.6664 \\
Training Participation & -0.030 & 0.012 & -2.495 & $0.0139^{* *}$ \\
Control & -0.072 & 0.0220 & -3.296 & $0.0010^{* * *}$ \\
Log Likelihood Ratio $: 51.4488$ & & & &
\end{tabular}

Note : $*$ significant on $0.1 ; * *=$ significant on 0.05 $* * *=$ significant on 0.01

Source: Primary Data 2018

Partially based on the result of tobit regression analysis in table 3 there are four factors that have a statistically significant effect on the inefficiency of shallots farming on the shallots farmers of UPSUS participant in Gondang sub-district at the significant level $0.5 \%$ and $0.01 \%$ that is farmer age, farming experience, UPSUS Program Training Participation, and control of UPSUS Program Officer. In detail all factors affecting technical inefficiency of shallots farming in Gondang Subdistrict are explained as follows:

\section{a. Farmer age}

Based on the results of tobit regression analysis obtained coefficient value from the age of farmers is positive, this means the age factor of farmers inversely proportional to the level of inefficiency at the age of farmers obtained coefficient value of 0.0052 which means if there is an additional age of farmers for one year it will increase the technical inefficiency of farmers by 0.0052 . The coefficient value of the age of farmers is positive. This means that the older age of farmers will result in the farmers become increasingly inefficient technically in managing the farming. This is in accordance with the initial hypothesis that the increase in age will increase the technical inefficiency of farmers.

b. Number of Family Member

The variable number of family members has a positive coefficient value on technical inefficiency and no statistically significant effect on shallots farming in Gondang Sub-district. Value coefficient number of family members of 0.017 which means if there is an increase in the number of family members as much as one person will increase the technical inefficiency of farmers of 0.017. This is because more family members are borne by the farmers will increase the technical inefficiency of farmers because the farmer as the head of the family has the responsibility to finance his family members so that the allocation of input costs will decrease production and farmers can not optimize the use of input.

c. Education Level

The education level variable obtained negative coefficient value to technical inefficiency and no statistically significant effect on shallots farming in Gondang Subdistrict. . The coefficient value of education level is -0.0015 which means that if the farmers take longer education it will decrease the technical inefficiency of farmers by 0.0015 . The level of education can represent the ability and skills of farmers academically so that through education expected farmers can improve productivity farming through appropriate decision making in the use of production inputs.

\section{d. Farming Experience}

Variable of farming experience obtained negative coefficient value to technical inefficiency and statistically significant effect on shallots farming in Gondang Sub-distric. The value of coefficient of experience of usahtani equal to $-0,0129$ which mean if farmer happened increase of ushatani 
experience by one year hence decrease technical inefficiency of farmer equal to 0,0129 . This is because the increasing experience of farmers in farming is believed to be able to minimize the risk of technical inefficiency in the farm.

e. Information and Technology Accsess

The information and technology access variable obtained negative coefficient value to technical inefficiency and no statistically significant affect on shallots farming in Gondang Subdistrict. The coefficient value of education level is -0.016 which means that the easier the information and technology that can be accessed by farmers will decrease the level of technical inefficiency equal to 0.016 .

\section{f. Training Participation}

The variables of thematic themed participation on the UPSUS APBN-P 2017 program are negative and statistically significant to the technical inefficiency of -0.0307 which means that if there is an increase of participation on the training once, it will decrease the technical inefficiency by 0.0307 . Function of Thematic Training UPSUS APBN-P 2017 is very important in distributing the latest information about technology, especially on shallot farming on UPSUS Program APBN-P 2017. So through thematic Training farmers can receive benefits in terms of information and application of the latest technology on shallots farming.

\section{g. Control}

The variable of UPSUS officers control in this study is negative and statistically significant to the technical inefficiency of -0.0725 which means that if there is an increase of control frequency from the counterpart at one time it will decrease the technical inefsience of 0.0725 . Control activities undertaken by escort officers include meeting and Focus Group Discussion (FGD) once a week with farmers who discuss about the constraints and problems faced in shallots farming. The existence of control activities from the assistant officers of UPSUS APBN-P 2017 Program makes farmers who get more control frequency can reduce the level of technical inefficiency.

\section{CONCLUSION}

The average technical efficiency level of shallots farmers in Gondang sub-district is 0.71 or with a percentage of $71 \%$ of the maximum production potential of shallots that can be achieved. As many as 52 farmers of shallots respondents in Kecamatan Gondang or with a percentage of $58 \%$ are technically efficient with technical efficiency values ranging from $0.700-0.950$. While the rest are as many as 38 farmers shallots respondents in District Gondang or with a percentage of $48 \%$ not technically efficient with an efficiency value of $\leq$ 0.699 or below the technical efficiency value limits.

The average technical efficiency level of shallots farmers in Gondang sub-district is 0.71 or with a percentage of $71 \%$ of the maximum production potential of shallots that can be achieved. As many as 52 farmers of shallots respondents in Gondang District or with a percentage of $58 \%$ are technically efficient with technical efficiency values ranging from 0.700 0.950 . While the rest of the country is in the Gondang district with a percentage of $48 \%$ not technically efficient with an efficiency value of $\leq 0.699$ or below the technical efficiency value limits.

\section{SUGGESTIONS}

Shallots farmers need to pay attention to the use of factors of production precisely by following the suggestion of input input from the Office of Agriculture Nganjuk through red shallots sops on Thematic Training Program UPSUS APBN-P 2017. In the results of this study found that seed input, urea fertilizer, $\mathrm{KCl}$ fertilizer, $\mathrm{ZA}$ fertilizer and labor have a statistically significant effect on the increase of shallots production.

To reduce the inefficiency of shallots farmers need to regenerate to more productive aged farmers. Besides, it needs to be socialized more intensively from related agents such as Dinas Pertanian, BPP, Kelompok Tani, and the universities which aims to increase farmers participation in following thematic training activities. Then control activities on shallot farmers need to be done intensively in order to overcome obstacles and problems so that can be obtained a quick and proper solution on shallots farming. 


\section{REFERENCES}

Apriani, Leni Nurul. 2011. Analisis Efisiensi Teknis dan Pendapatan Usahatani Bawang Merah di Kabupaten Majalengka, Jawa Barat. Institut Pertanian Bogor. Bogor.

Asmara, Rosihan. (2017). Efisiensi Produksi : Pendekatan Stochastic Frontier da Data Envelopment Analysis (DEA). Jurusan Sosial Ekonomi Pertanian Universitas Brawijaya. Malang

Badan Penelitian dan Pengembangan Pertanian. (2015). Pedoman Teknis Hortikultura. Kementrian Pertanian. Jakarta

Balai Penyuluhan Pertanian Kecamatan Gondang. (2017). Laporan Identifikasi Potensi Wilayah Kecamatan Gondang. Nganjuk

Bifarin JO, Alimi T, Bbruwa OI, Ajewole OC. (2010). Determinant of Technical, Allocative and Economic Efficiencies in the Plantain (Musa spp) Production Industry Ondo State. University of Ado-Ekiti. Nigeria

Coelli. T.J. D.S.P.Rao and Battese, G.E and. (1998). An Introduction to Efficiency and Productivity Analysis. Kluwer Academic, Boston

Coelli. T.J. D.S.P.Rao and Battese, G.E and. (2005). An Introduction to Efficiency and Productivity Analysis. Springer, New York

Dinas Pertanian Nganjuk. (2017). Standard Operasional Prosedural (SOP) Bawang Merah. Dinas Pertanian Nganjuk. Nganjuk

Ferrel, M.J. (1957). The Measurement of Productive Efficiency. Journal of the Royal State Society. Vol $120: 253-290$

Geta, E. Bogale. Kassa and Eyasu. 2013. Producticity and Efficiency Analysis of Smallholder Maize Producers in Southern
Ethiopia. Journal of Hum. Ecol Vol. 41 (1): pp $67-75$

Kementrian Pertanian (2016). Pedoman Umum Hortikultura. Departemen Pertanian. Jakarta

Khumbakar, S. and Lovell, C. (2000). Stochastic Frontier Analysis. University of Cambrige. Cambrige

Khumbakar. (2002). Spesification and Estimation of Production Risk, Risk Preference, and Technical Efficiency. American Journal of Agriculture Vol. $84: 8-22$

Mutiarasari, Nurul Risti. 2017. Analisis Efisiensi Usahatani Bawang Merah di Kabupaten Majalengka, Jawa Barat. Institut Pertanian Bogor. Bogor

Purmayanti, S. (2002). Analisis Produksi dan Daya Saing Bawang Merah di Kabupaten Brebes Jawa Tengah. Institut Pertanian Bogor. Bogor

Pusat Data dan Informasi Pertanian. (2016). Outlook Bawang Merah 2016. Departemen Pertanian. Jakarta

Rogers, M. (1998). The Definition and Measurement of Productivity. The University of Melbourne Institute of Applied Economics and Social Research. Working Paper 9/98

Tobin, J., (1958). Estimation of Relationship for Limited dependent Variables. Econometrica 26. 263-85

Waryanto, Budi. (2015). Analisis Keberlanjutan Usahatani Bawang Merah di Kabupaten Nganjuk Jawa Timur. Institut Pertanian Bogor. Bogor

Wassie, Solomon Bizuayehu. (2012). Technical Efficiency of Major Crop in Ethiopia : Stochastic Frontier Model. Academica Journal of Research 2(6) : 147 